\title{
VOICES OF POLITICAL WOMEN ON WOMEN ISSUES IN THE MEDIA: A CASE OF PAKISTAN'S 2013 ELECTIONS
}

\author{
Bushra H Rahman* \\ Fakiha Rizvi** $^{* *}$
}

\begin{abstract}
The study examines if women politicians of Pakistan in the media are portrayed as effective decision-makers who demonstrate their leadership abilities and dynamism in advocating women issues. It aims to study whether media was used as an organized effort to use political women to bring social and economic improvement in the status of women by examining the Pakistani media on the issues of women during Pakistan's 2013 general elections. It explores the assumption put forward by the 'critical mass theory', that if women form the critical mass in the political power structure, they have a major effect on becoming a voice in the media for women issues. It is a content analysis of articles, editorials and features of four major dailies and talk shows of three major television channels during the Pakistan's election year 2013. Findings show that women issues were just not sidelined but also women politicians were marginalized in the media to talk on women issues. The discourses on women by 'empowered' women were almost non-existent in the media.
\end{abstract}

Keywords: political women, Pakistan, elections 2013, media portrayal

\section{Introduction}

The presence of women in the corridors of power and on important positions is a topic under debate since women were granted the right to cast vote. Women politicians are now taken as legitimate focus for analysis. Female political representation covers how well women are represented in all decision-making structures. Their political representation constitutes gender-equity (a step further than gender-equality). Progress has been quite significant in the last few years to clear the inlet for female politicians into the domain of politics. Compared to the gender gap in the other areas measured by the World Economic Forum in 2014, politics stands out as scandalously unequal: health has a small gender gap of $4 \%$, education of $6 \%$, economic participation of $40 \%$, and politics an exceptionally high $79 \%$. Despite the positive dynamics of recent years, having just one woman for every four men in politics is a clear indication of how seldom societies are tapping into the potential talent of more than $50 \%$ of their population that consists of female citizens. There are important variations, like in Nordic countries are the most gender equal, with women at $41.6 \%$ of the total number of Parliamentarians.

\footnotetext{
*Bushra H Rahman, Ph.D. Assistant Professor, Institute of Communication Studies, University of the Punjab, Lahore

*** Fakiha Rizvi, Graduate. Freelance writer
} 
The world champion for women participation in politics is Rwanda where women constitute $64 \%$ of the Chamber of Deputies: this year Rwanda is ranked seventh in the world for gender parity. There are also differences among the participation of women in developing and developed countries. For instance, in South Asia, women are generally under-represented in the high level power structure specially the countries which are not observing quotas in their parliaments for the representation of their women population. The marginalized participation and presence of women in the political affairs of any country is governed by various factors ranging from the interests of female gender to the social norms and value system of the society. When it comes to women in positions of political leadership in particular, it would take even longer still for the gap to close.

To explore 'gender' dimension in political research has gained significant importance and acceptability recently. The participation of women when they have accepted leadership positions also demands attention as their presence needs to illicit increased and easy access to political positions for the coming female generation and also work for other issues concerning women. Corwall and Goetz in 2005, have highlighted the important lessons to be learnt from initiatives such as "Brazil's escolas feministas" where women were trained to build their capabilities as feminists of would-be politicians and women representatives in other democratic spaces. The role of media in this regard is of relevance. The socio-political involvement of women and their portrayal in the mainstream media allows them to build alliances, empower women in their countries and to enable them to resonate their voices against gender imbalances occurring in the society.

Though there has been an increase in the coverage of women in the media, the question remains that does the participation in politics and access of women to the media has any impact on and use as an instrument for the advancement and empowerment of women. On TV news coverage in Israeli elections 2008 Lanchover (2012) demonstrates that though the coverage on women was quite minimal, which is also a reflection of socio political reality of the country where women politicians are still a minority, it was quite complex also. On the one hand media mirrored the patriarchal power structure, subordination of women to men was apparent but on the other hand media also offered a forum for genuine feminist discourse(Lachover 2012). Pini in 2008, argues that though in the past Australian media was considered to be woman friendly state, 'femcorats' were overseeing gendered policy analysis of mainstream programs as well as broad range of women's service. However, recently feminist's agenda are marginalized. Women capacities and needs are selectively recognized. This has significantly shifted the dominant discourses on women (Pini, Panelli et al. 2008).

While exploring the point of view of media practitioners in covering women's issues and perspective Minic in 2008, states that there are number of factors which influence their selection of issues and the ways they approach them. Amongst them is the identity of the program, its issues, voices and their diversity; the listeners; the professional and institutional context of the program. She argues that a program on women combines and oscillates between recognition and deconstruction of women'/gender identities , producers' interest and the perceived interests of their audiences, and feminist politics and journalistic principles (Minic 2008). 
Women participation in politics in Pakistan has increased considerably in the last couple of decades, and projection of female gender and women issues is now an oft-repeated debate in Pakistan. Since 2001, the mushrooming of private media outlets has gained pace and almost all the television channels consider inviting female politicians in talk shows. In this context this study aims to examine whether Pakistani politicians are given a chance to speak in the media on the issues of women or not, and even if they are invited, on which issues of women they have been given a chance to speak.

\section{Critical Mass}

A pivotal concept in research on women's political representation is the concept of 'critical mass'. It is frequently used to explain why women do not always appear to represent/dedicatedly represent women once they are in political office. Researchers, scholars, women rights activists and those who work on gender and politics suggest that this pattern is not due to the inclinations of female office holders, but rather to the fact that there are fewer women than men in almost all elected assemblies. They argue that women are not likely to have a major impact on legislative outcomes until they grow from a handful of individuals collected just to fill reserved slots into a considerable minority of all legislators: only as their numbers increase will women be able to work more effectively together to promote women-friendly policy change and to influence their male colleagues to accept and approve legislation promoting women's concerns.

Over the last twenty years, 'critical mass' has gained wide currency among politicians, the media and international organizations as a justification for measures to bring more women into political office (Grey, 2006; Krook, 2005). As Norris and Lovenduski (2001, p.3) explain, when a group remains a distinct minority within a larger society, its members will seek to adapt to their surroundings, conforming to the predominant rules of the game, but once the group reaches a certain size, critical mass theory suggests that there will be a qualitative change in the nature of group interactions, as the minority starts to assert itself and thereby transform the institutional culture, norms and values.

Blondet (2000) has carried out a detailed study on how the participation of women in political and economic decision-making in Peru has led to the promotion of discussion on issues and the proposal of laws that defend women's rights. Htun \& Piscopo (2010) have argued that women's presence in power in Latin America and the Carribean "has also correlated with change to some policies related to women's rights. Most countries have adopted measures to prevent and punish violence against women".

The findings of Vega and Firestone (1995) on gender representation in the parliament and legislation on women, demonstrate that women related bills are proportional to the number of congressional women. Their findings suggests that congressional women display a distinctive legislative behavior which is significant in representing women and women issues(Vega and Firestone 1995). Likewise as women become more senior the chances of their becoming more vocal in raising women issues become greater.

However, it is also observed that female politicians adhere to and fulfill the responsibilities assigned to them, like any politician from the opposite gender. It is also 
argued that though, women are being incorporated more into parliamentary democracies it is not necessary that they become targets for media on pursuing feminist politics(Ross 2000). There is a growing concern that neither political parties who incorporate women in their parties have issues of women on their agenda nor media take women politicians seriously on women issues. What is observed is that while analyzing the contribution of female politicians towards women issues other than their political participation, more emphasis is given to their right to be represented in democratic arenas and less to other 'new' democratic spaces which are outside formal politics. Likewise, it is also argued that the party policy mattered more than the presence of women in the parliament.

\section{Status of Pakistani Women in National Politics}

Women of Pakistan have been actively involved in politics ever since the creation of Pakistan. They have been helping to organize political campaigns, raise funds, recruit and organize women in joining political parties. The origin of the female participation can be tracked before the inception of the state of Pakistan on the map of this world. Starting from Pakistan movement, female political workers actively participated in safeguarding the rights of Muslim minority in united India. Pakistani women are accepted in politics mostly if they are related to male political leaders by blood or marriages. A hundred and eighty six women were elected between 1947 and 1999. However, their recognition is by constantly linking them with the respective male relation. Fatima Jinnah was known as Quaid-i-Azam's sister, Begum Liaquat Ali Khan was known as Liaqat Ali's wife, Benazir Bhutto was Bhutto's daughter, Maryam Nawaz Sharif is known as Nawaz Sharif's daughter. It is also argued that Pakistani politicians include women leaders and party workers to gain the vote of 40 million eligible women to vote (Shah 2013).

To provide context, brief demographic summary of the Pakistani political landscape is that Pakistan has a population of 187 million people, the male population stands around 96 million and female population around 91 million. According to the Election Commission of Pakistan (ECP) there are 38.8 million male registered voters and 37.6 million female registered voters, two million voters more than 2008. In the 2013 Election the turnout was impressive as nearly $50 \%$ of the registered female voters cast their votes even from the Federally Administered Tribal Areas, despite some efforts to bar them from voting in such parts. The voters' numbers indicate increasing commitment on the part of the female electorate to democracy. Another reason for increased participation could be the efforts of the Computerized National Identity Card Drive.

The National Assembly of Pakistan has a total number of 342 seats, which includes 60 reserved seats for women and 10 seats for non- Muslims. This amounts to nearly $20 \%$ reserved seats in the National Assembly and $18 \%$ in the Provincial Assemblies. After the 2013 elections only 17 women were elected on direct seats and account for only $3 \%$ of the seats in the National Assembly and Provincial Assembly. Of this, 10 members belong to PPP, 3 to PML (N), 3 to PML (Q) and one Independent candidate later joining PML(N). Of these 17 female members, 5 belong to Sindh and remaining to Punjab. There is no single female member from KPK and Baluchistan. 
Election 2013 reflects impressive gains for women with increased number of candidates and voters. A large number of first time women candidates were given opportunity to contest elections under different political parties. In the 2013 election, out of the 463 female candidates, 17 women were elected for 342 seats in National and 577 seats in the four Provincial Assemblies. According to The Researchers (TR) and Women and Politics in Asia Forum (WPAF) report at the national level in the 111 constituencies 150 women filed nomination papers out of which 60 were on party tickets. At provincial levels for 213 constituencies 313 filed nomination papers and 115 were on party tickets. Analyzing the results of 2013 the report stated that one factor that clearly emerged was that the voters cast their votes for the political party rather than the candidates.

Despite the welcome addition of more women contesting elections independently on general seats of the National Assembly, in the mainstream political parties the number of women candidates contesting in the general elections has remained unchanged. The figures show increased participation of women in the political sphere. However, they have difficult time in holding positions of leadership within Pakistani political parties. They are discouraged from taking prominent positions which might be due to social restraint of getting into public appearances and contact with strangers.

Though inclusion of women in political parties is a wise move, unless they are placed in leadership positions, women of Pakistan will not be able to see that their voice and vote matters. The present government has so far no woman in the federal cabinet, and they are not grooming women to contest elections independently on party tickets and keeping the tradition of letting women enter the parliament through reserved seats. Despite their under representation various studies have shown that during 2010-2013, women have played a more effective role in parliament compared to their male counterparts. They have been seen to give priority to social issues, education, health, population welfare that have been overlooked for decades by men in parliament (Mirza, 2011).

In this context it is crucial to examine media representation of political women, as mediated spaces are critical sites to examine how seriously she is taken in political arena for issues of women. Electronic media plays a vital role in Pakistan where literacy rate is not impressive. By highlighting political awareness about national issues among the people, the electronic media sensitizes the public about the overall situation of their country. The print media of Pakistan is divided into two categories on language basis, English and Urdu. English dailies are mainly for the elite class involved in policy making and Urdu dailies are mainly for common man. In this regard, it is imperative to find out that how the media represents elected political women on issues related to women when they appear in the electronic media or when their statements make it to the headlines of the national newspapers.

This study aims to empirically examine whether media during the election 2013 sensitized the public on women issues through women politicians or not. It aims to analyze the difference in the coverage of women issues in two different forms of Pakistani media while simultaneously analyzing the issues when women politicians were given a chance to provide their opinion in prime time talk shows being aired on most-viewed television channels of Pakistan and in the newspapers that have a healthy readership. 


\section{Research Questions}

RQ1. Did prime time talk shows give prominence to women issues through women politicians?

RQ2. Did print media give coverage to women issues addressed by women politicians?

\section{Methodology}

This study considers prime time shows of three major channels, Geo, Dunniya, and Express from January, 2012 till May, 2013. A total of 735 talk shows were looked in the three channels and only in 138 (18.7\%) talk shows women were invited which were selected for the study. Political women and non-political women were identified. Out of total of 138 talk shows in $90(65.2 \%)$ talk shows women politicians were invited and in $40(28.9 \%)$ talk shows non-political women (either human rights activists or women experts) were invited.

Issues were identified which were of national and international nature and were divided into five categories - political, social, economic, human rights and women. Women issues were further divided into three categories - where women were encouraged to participate in politics; issues of women discussed in political parties' agenda and other social issues related to women.

This paper also considered two English dailies-Dawn and The News and two Urdu dailies- Jang and Express from March 25, till May 25, 2013. The unit of analysis were all news pages, opinion pages, magazine section and special pages on 2013 Election which had any reference to women in politics or issues of women. Three categories were of analysis: one was on political women and their political profile or statements not related to women; second was on political women and issues of women either in statement form or in any political event dealing with women; third category was on women issues but did not have any reference to women politicians.

\section{Findings and Discussion}

Table 1: Issues in the prime time talk shows of three leading Pakistani news channels

\begin{tabular}{|l|l|l|l|l|}
\hline Issues & $\begin{array}{l}\text { Women } \\
\text { politicians }\end{array}$ & $\begin{array}{l}\text { Non-political } \\
\text { women }\end{array}$ & Both & Total \\
\hline political & 87 & 22 & 1 & $110(79.7 \%)$ \\
\hline social & 3 & 3 & 0 & $6(4.3 \%)$ \\
\hline economic & 3 & 0 & 0 & $3(2.2 \%)$ \\
\hline $\begin{array}{l}\text { human } \\
\text { rights }\end{array}$ & 0 & 12 & 1 & $13(9.4 \%)$ \\
\hline women & 4 & 2 & 0 & $6(4.3 \%)$ \\
\hline
\end{tabular}

$\mathrm{N}=138$; Political women $\mathrm{n} 1=98$; non-political women $\mathrm{n} 2=40$

First research question dealt with the coverage on women issues by women politicians. A chi-square test of goodness-of-fit was performed to determine whether the five issues 
were equally preferred in the selected talk shows or not. Preference for the five issues was not equally distributed in the population, $\mathrm{X} 2(4, \mathrm{~N}=138)=309.46, \mathrm{p}<.000$ which shows that there was a significant difference between the categories. Findings in Table 1 show that out of total of 138 talk shows in 110 (79.9\%) talk shows women were called to discuss issues on political matters of national or international political interest. In these talk shows in 87 talk shows women politicians were invited and in 22 non-political women were invited. Whereas, on social and economic issues in $6(4.3 \%)$ and $3(2.2 \%)$ talk shows women were invited to speak. Only in 6 talk shows, they were given a chance to speak on the issues of women. Out of these 6 talk shows, four had women politicians and only two had non-political women talking on women issues.

Table 2: Women issues discussed by political and non-political women in the prime time talk shows

\begin{tabular}{|l|l|l|l|l|}
\hline Issues & $\begin{array}{l}\text { Women } \\
\text { politicians }\end{array}$ & $\begin{array}{l}\text { Non-political } \\
\text { women }\end{array}$ & both & Total \\
\hline other than women issue & 93 & 37 & 2 & $132(95.7 \%)$ \\
\hline $\begin{array}{l}\text { political participation of } \\
\text { women }\end{array}$ & 1 & 1 & 0 & $2(1.4 \%)$ \\
\hline $\begin{array}{l}\text { issues of women in the } \\
\text { political parties' agenda }\end{array}$ & 1 & 0 & 0 & $1(0.7 \%)$ \\
\hline $\begin{array}{l}\text { social issues related to } \\
\text { women }\end{array}$ & 2 & 1 & 0 & $3(2.2 \%)$ \\
\hline
\end{tabular}

$\mathrm{N}=138$; Political women $\mathrm{n} 1=98$; non-political women $\mathrm{n} 2=40$

Findings in Table 2 show that women were hardly given any opportunity to speak on social issues of women $(2.2 \%)$, they were called to speak on their political participation only twice $(1.4 \%)$ in the selected period and on the issues of women as political parties agenda they were called only once $(0.7 \%)$ to express their views.

Table 3: A comparative language wise issues on women in the four dailies of Pakistan

\begin{tabular}{|l|l|l|l|}
\hline & $\begin{array}{l}\text { Women } \\
\text { politicians }\end{array}$ & $\begin{array}{l}\text { Women politicians } \\
\text { and women issues }\end{array}$ & $\begin{array}{l}\text { Women } \\
\text { issues }\end{array}$ \\
\hline English Dailies & $114(93.4 \%)$ & 0 & $8(6.5 \%)$ \\
\hline Urdu Dailies & $118(100 \%)$ & 0 & 0 \\
\hline Total & 232 & 0 & 8 \\
\hline
\end{tabular}
$\mathrm{N}=240$; English dailies $\mathrm{n} 1=122$ Urdu dailies $\mathrm{n} 2=118$

Out of total of 240 news items $232(96.6 \%)$ were on women politicians, only 8(3.3\%) highlighted the issues of women during the elections period and, none were on women politicians making any news or statements on issues of women. Another interesting finding is that all the articles on women issues were in English dailies, none were in Urdu dailies. The articles in English dailies carried social issues like the state of women's education, health, and crime. The articles emphasized the need to include issues of women in the political parties' manifesto along with the importance of women taking part in active politics. 
Table 4 : Genre wise issues on women in the major dailies of Pakistan

\begin{tabular}{|l|l|l|l|l|}
\hline & $\begin{array}{l}\text { Women in } \\
\text { politics }\end{array}$ & $\begin{array}{l}\text { Women } \\
\text { politicians and } \\
\text { women issues }\end{array}$ & Women issues & total \\
\hline only pictures & 66 & 0 & 0 & 66 \\
\hline News & $126(97.6 \%)$ & 0 & $3(3.4 \%)$ & 129 \\
\hline columns & $11(91.6 \%)$ & 0 & $1(8.35)$ & 12 \\
\hline editorials & 0 & 0 & 0 & 0 \\
\hline features/articles & $29(87.8 \%)$ & 0 & $4(12.1 \%)$ & 33 \\
\hline
\end{tabular}

$\mathrm{N}=240$

In the genre wise distribution of articles on issues of women, only three (3.4\%) news were on women issues, one column, four $(12.1 \%)$ feature articles and no editorials in the dailies. The overall coverage on women issues was far from satisfying during the election 2013 period. There was no editorial coverage on women issue and the need for her political participation. The fact that there was no editorial coverage on women issues speaks volumes of how women issues were just not marginalized but also completely ignored in the Pakistani dailies.

\section{Conclusion}

The study aimed to examine how Pakistani media performed with regard to creating more space for women politicians and more importantly setting a proactive agenda for working towards gender equality by giving coverage to women issues, in the 2013 Elections, and how political and non-political women's voices and images as forms of expression found presence in media for women issues in the election of 2013.

The findings clearly provide evidence that though rarely, political women in Pakistan are opining about political issues of the country and matters of national interest ranging from governance to foreign relations. The 'empowered' political women have been given coverage as women who are more conversant with the political issues of the country and the non-political women presence on issues like human rights issues are apparent. However, both political and non-political women are missing out in the media on the issues of women especially their political development and increased representation in major position of power/decision-making. Rarely in prime time talkshows, women issues were raised and in which women politicians were invited. Media ignored women issues during the 2013 Election campaign, and women politicians were hardly given any opportunity to talk about their social political issues. The findings explicitly suggest the media reflected dearth of women issues in the political agendas of women politicians and political parties. Issues of her health, education, crime etc., were virtually non-existent on the media agenda and hence women politicians were also hardly invited on the issues.

There was not a significant difference in the electronic and print media on the coverage of women issues. In the talk shows though scarcely women politicians were scarcely called to talk on women issues, in the print media no women politician or other 
women's statements on women issues were ever made a news or part of any other editorial content. English press occasionally dealt with the political participation of women along with the need to address their issues in the political campaigns, but Urdu dailies did not just ignore the issues of women but also ignored their political participation in the election process. The Urdu press which is read more widely, and consequently less elitist, completely ignored women issues and did not form any agenda on women issues for its readers. It only demonstrates that the vast majority of Pakistan's which is exposed to Urdu dailies is not educated and sensitized about the socio economic issues of women and never regards them as issues to be considered in the political campaigns and political parties' manifesto.

Considering the concept of 'critical mass', it can be concluded that women politicians are still under-represented in direct elections in Pakistan (both in the parliament and in the media). Consequently, fewer voices are resonating related to women issues and more can be read and heard about the themes that the media itself wants women to opine about (politics being on the top of the list). As the 'critical mass' concept suggests, women are not likely to have a major effect on the outcomes of legislative processes and change in policy until they grow from a handful of individuals collected just to fill reserved slots into a considerable minority of all legislators(Vega and Firestone, 1995). The argument that if only their numbers increase will women is able to work more effectively together to promote women-friendly policy change and to influence their male colleagues to accept and approve legislation promoting women's concerns is not good enough. It is proposed that it is not just the increased number that matters but also that the female politicians and media need to be made more erudite to talk on women issues. To make their voices recognized and respected, more media-time to women issues in prime time shows and in the editorial coverage in the print media can also trigger increased and productive discussion on women issues by women politicians. To improve the sociopolitical status of women an increased participation of women in the parliament and in the media is required. An organized and integrated effort to use political participation of women communication through media is required to bring around the discourses to bring the socio-economic and political changes to empower women of all sections of the society.

\section{References}

Bawa, Sylvia \& Sanyare, Francis (2013). Women's Participation and Representation in Politics: Perspectives from Ghana, International Journal of Public Administration, And 36:4, 282-291, DOI: 10.1080/01900692.2012.757620

Cornwall, Andrea \& Goetz, A. Marie (2005). Democratizing Democracy: Feminist Perspectives, Democratization, Vol.12, No.5, 783-800, DOI: $10.1080=13510340500322181$

Grey, S. (2006) 'New Zealand', in M. Sawer, M. Tremblay and L. Trimble (eds), Representing Women in Parliament: A Comparative Study. New York: Rutledge, pp. 134-51 
Krook, M. L. (2005) Politicizing Representation: Campaigns for Candidate Gender Quotas Worldwide. Unpublished PhD thesis, Department of Political Science, Columbia University, February.

Lachover, E. (2012). “Just Being a Woman Isn’t Enough Any More: Israeli television news of women in local politics." Feminist Media Studies12(3): 442-458.

Minic, D. (2008). "What Makes An Issue A Woman's Hour Issue? The politics of recognition and media coverage of women's issues and perspectives." Feminist Media Studies8(3): 301-315.

Mirza, N (2011) Seven pro women laws in seven years, Legislative Watch 38 (December) retrieved from http://www.af.org.pk/Newsletters/nl\%202011/NLE\%20English\%20-\%2038.pdf

Nogueira, M. Conceição (2009). Women in Positions of Power in Portugal: Contradictory Positions and Discourses, Journal of Women, Politics \& Policy, 30:1, 7088, DOI: $10.1080 / 15544770802367804$

Norris, P. and Lovenduski, J. (2001) Blair's Babes: Critical Mass Theory, Gender, and Legislative Life, John F.Kennedy School of Government Harvard University, Faculty Research Working PapersSeries.

Pini, B., R. Panelli, et al. (2008). "Managing the woman issue: The Australian state and the case of women in agri-politics." International Feminist Journal of Politics10(2): 173197.

Ross, K. (2000). "Unruly theory and difficult practice: Issues and dilemmas in work with women politicians." International Feminist Journal of Politics2(3): 319-336.

Shah, B. (2013). Political parties need women leaders. DAWN.com.The Researchers (Press release) retrieved from http://www.theresearchers.org/Publications/Press\%20Release/Nation\%20Elects\%2016 $\% 20$ Women $\% 20$ Representatives $\% 20$ out $\% 20$ of $\% 20463 \%$ 20Candidates.pdf

Vega, A. and J. M. Firestone (1995). "The effects of gender on congressional behavior and the substantive representation of women." Legislative Studies Quarterly: 213-222. 